\title{
ANALISA PENGGUNAAN SKEMA KONTROL DAYA BERBASIS WATERFILLING DAN ALGORITMA ALOKASI MEAN-GREEDY PADA SISTEM LONG TERM EVOLUTION (LTE)
}

\author{
Vinsensius Sigit Widhi Prabowo ${ }^{1}$, Brian Pamukti², \\ ${ }^{1,2}$ Fakultas Teknik Elektro, Universitas Telkom, Bandung, Indonesia \\ 1vinsensiusvsw@telkomuniversity.ac.id, ${ }^{2}$ brianp@ telkomuniversity.ac.id,
}

\begin{abstract}
Abstrak
Sistem komunikasi nirkabel diharapkan menjadi suatu sistem yang dapat menyajikan kualitas layanan yang cepat, handal, dan efisien. Oleh karena itu, diperlukan skema manajemen sumberdaya yang baik untuk mencapai parameter performansi tersebut. Penelitian ini berfokus pada skema manajemen sumber daya pada sistem Long Term Evolution yang tidak hanya mengejar parameter performansi dasar seperti efisiensi spektral dan fairness sistem, tetapi juga mempertimbangkan aspek efisiensi energi. Penambahan skema kontrol daya waterfilling digunakan pada algoritma alokasi mean greedy untuk mengatur daya pada tiap-tiap resource block (RB). 2 Skema yang digunakan adalah normal waterfilling (NWF) yang memberikan daya lebih pada user dengan kondisi kanal buruk dan Inverse Waterfilling (IWF) yang mengalokasikan daya lebih pada user dengan kondisi kanal baik. Dari hasil simulasi didapatkan skema NWF menaikkan fairness sistem sebesar 10\% tetapi menurunkan nilai efisiensi spektral sebesar $1,02 \mathrm{bps} / \mathrm{Hz}$, dan menurunkan efisiensi energi sebesar $68,75 \mathrm{kbps} / \mathrm{Watt}$. Sebaliknya, skema IWF meningkatkan efisiensi spektral sebanyak $1,42 \mathrm{bps} / \mathrm{Hz}$, dan meningkatkan efisiensi energi sebanyak 205,67 kbps/Watt, tetapi fairness sistem menurun sebesar $11 \%$. Dapat disimpulkan, skema NWF baik untuk sistem yang mengedepankan keadilan sistem dan stabilitas koneksi, sedangkan skema IWF lebih sesuai diterapkan pada sistem yang mengedepankan efisiensi.
\end{abstract}

Kata Kunci: mean-greedy, waterfilling, kontrol daya, efisiensi energi

\section{Abstract}

Wireless communication requested to provide a fast, reliable, and efficient service. A good resource management is needed to achieve better performance. This works tried a resources management scheme on Long Term Evolution (LTE) system that not only achieve good base performance like spectral efficiency and system fairness, but also considering the energy efficiency aspect. Waterfilling power control scheme is added to mean-greedy allocation algorithm to control the power of each resource block (RB). there are 2 scheme that being used are Normal Waterfilling (NWF) which try to allocates more power to bad channel user, and Inverse Waterfilling which try to allocates more power to good channel user. Simulation results show that NWF can improve the system fairness up to $10 \%$ but the spectral efficiency decreased by $1,02 \mathrm{bps} / \mathrm{Hz}$, and the energy efficency decreased by $68,75 \mathrm{kbps} / \mathrm{Watt}$. In contrary, the IWF scheme can improve the spectral efficiency by $1,42 \mathrm{bps} / \mathrm{Hz}$, and increase the energy efficiency by $205 \mathrm{kbps} /$ Watt, but the system fairness decreased by $11 \%$. Can be conclude that NWF scheme is a good use for a system that prioritize fairness and connection stability, meanwhile IWF scheme is more appropriate for a system that want to achieve better efficiency.

Key Words: mean-greedy, waterfilling, power control, energy efficient

\section{Pendahuluan}

Sistem Long Term Evolution (LTE) sudah menjadi standar baru di sistem komunikasi nirkabel. Sistem LTE menggunakan skema Orthogonal Frequency Divison Multiple Access (OFDMA) yang membagi 1 bandwidth carrier menjadi beberapa sub-carrier yang lebih kecil yang disebut resource block (RB). Nantinya tiap-tiap RB akan dialokasikan kepada user-user spesifik untuk melakukan komunikasi.
Diperlukan skema manajemen sumber daya dan algoritma alokasi yang baik untuk mencapai tingkat performansi sistem yang baik. SAlah satu algoritma yang sering digunakan adalah algoritma greedy. Algoritma greedy merupakan algoritma alokasi yang memperbolehkan user memilih RB terbaik pada tiap proses pengalokasian. Pengembangan dari skema ini adalah algoritma mean-greedy, yang terlebih dlu memberikan nomor urut kepada user. Nomor urut ini 
didasarkan pada rata-rata kualitas masing-masing user. User dengan rata-rata kualitas paling besar diberika nomor urut kecil. begitu sebaliknya.

Pada penelitian [1] diusulkan algoritma alokasi proportional fair yang mencoba meningkatkan keadilan pada sistem OFDM. Pada penelitian [2] skema modifikasi algoritma greedy juga dipakai untuk meningkatkan performansi sistem pada jaringan matajala (mesh network). Pada penelitian [3] dianalisa tentang penggunaan skema mean-greedy pada sistem komunikasi multi-carrier. Skema mean-greedy dan modifikasinya juga dicoba pada sisi uplink pada penelitian [4] [5] [6]. Skema algoritma alokasi mean-greedy juga dicoba diterapkan pada sistem LTE-Advanced dengan carrier aggregation seperti pada penelitian [7] dan [8].

Skema mean-greedy memiliki performansi untuk menjaga efisiensi spektral dan juga fairness secara keseluruhan. Tetapi pada masa ini, performansi sistem tidak hanya ditinjau dari efisiensi spektral maupun keadilan sistem saja. Tingkat efisiensi energi juga mulai menjadi parameter performansi yang dipertimbangkan. Muncullah skema kontrol daya berbasis waterfilling yang mencoba mengontrol daya berdasarkan kualitas masing-masing user.

Dasar dari skema kontrol sudah beberapa kali diterapkan dalam manajemen sumber daya radio. Penelitian [9] menerapkas skema kontrol daya pada jaringan LTE heterogen, dan berhasil mendapatkan tingkat efisiensi energi yang lebih rendah. Skema waterfilling juga telah dicoba pada sistem LTE dengan skema MIMO (multiple input multiple output) pada penelitian [10].

Pada penelitian ini akan disimulasikan 2 skema kontrol daya berbasis waterfilling. Yang pertama adalah skema normal waterfilling yang memberikan power lebih kepada user dengan kualitas koneksi rendah [11]. Hal ini bertujuan untuk menjaga kualitas layanan di tiap user sehingga keadilan sistem dapat terjaga. Skema kedua adalah inverse waterfilling yang memberikan power lebih kepada user dengan kualitas baik [11]. Hal ini dimaksudkan untuk meningkatkan efisiensi spektral sistem.

\section{Model Sistem}

Penelitian ini akan menguji algoritma alokasi mean-greedy dengan skema kontrol daya berbasis waterfilling. Algoritma ini akan disimulasikan pada sistem LTE. Cell yang ditinjau bersifat berdiri sendiri (single cell) tanpa ada interferensi dan pengaruh dari cell lain disekeliling. Total jumlah user adalah $N$ dan total jumlah RB adalah $V$. Pada 1 kali proses alokasi (1 TTI / Time Transmission Interval), user dianggap tidak bergerak dan tidak melakukan handover. Setiap subcarrier pada sistem pun dianggap saling orthogonal sehingga tidak ada interferensi antar subcarrier (intracell interference)

Sebelum dilakukannya manajemen sumber daya, setiap user akan mengukur kualitas semua resources block (RB) yang ada pada sistem dengan menganggap semua daya sistem terbagi rata ke setiap RB yang ada. Langkah ini dilakukan dengan perhitungan [11]:

$$
C_{n, v}(s)=P_{v} \cdot H_{n, v}(s) .
$$

Dimana $P_{v}$ adalah daya pada masing-masing RB (dianggap sama pada proses pengukuran kualitas awal), dan $H_{n, v}(s)$ adalah atenuasi yang terjadi pada hubungan antara user ke-n dan RB ke-v pada iterasi ke-s. Nantinya hasil perhitungan kualitas setiap user pada setiap RB ini akan dimasukkan kedalam suatu matriks Channel State Information (CSI) yang nantinya akan digunakan sebagai input dari algoritma manajemen sumber daya itu sendiri. Matriks CSI ini akan mengikuti persamaan :

$$
\operatorname{CSI}(s)=\left(\begin{array}{ccc}
C_{1,1}(s) & \cdots & C_{1, V}(s) \\
\vdots & \ddots & \vdots \\
C_{N, 1}(s) & \cdots & C_{N, V}(s)
\end{array}\right)
$$

\subsection{Formulasi Masalah}

Tujuan utama dari penelitian ini adalah menganalisa performansi algoritma mean-greedy dengan skema waterfilling pada sistem LTE. Ada beberapa ketentuan yang harus dipenuhi antara lain sebagai berikut.

$$
\begin{gathered}
\sum_{n=1}^{N} \alpha_{n, v}=1 ; \forall_{v} \in V . \\
\sum_{n=1}^{N} \sum_{v=1}^{V} \alpha_{n, v}=V . \\
\beta_{n, v} \in[0, x] \mid x \leq P_{t} ; \forall_{v} \in V ; \forall_{n} \in V . \\
\sum_{n=1}^{N} \sum_{v=1}^{V} \beta_{n, v} \leq P_{t} . \\
\alpha_{n, v} \neq 0 \rightarrow \beta_{n, v} \neq 0 ; \forall_{v} \in V ; \forall_{n} \in N .
\end{gathered}
$$

$\alpha$ adalah matriks alokasi. $\alpha_{n, v}=1$ jika RB ke-v dialokasikan pada user ke-n, jika tidak maka $\alpha_{n, v}=0$. Sementara $\beta$ merupakan matrik alokasi daya. Persamaan 3 menyatakan bahwa 1 RB hanya dapat dipakai oleh 1 user secara spesifik, tanpa bisa digunakan oleh user lain. Persamaan 4 memastikan semua RB harus teralokasi kepada 1 spesifik user. Persamaan 5 dan 6 memastikan daya yang diberikan kepada tiap RB tidak melebihi daya total pada sistem $P_{t}$. Persamaan 7 memastikan setiap RB mendapatkan daya.

\subsection{Algoritma Alokasi Mean-Greedy}

Algoritma mean-greedy (MG) adalah modifikasi dari algoritma greedy yang mencoba memaksimalkan 
antara fairness dan efisiensi spektral. Matriks CSI pada persamaan 2 akan digunakan sebagai input dari algoritma ini. Secara keseluruhan, algoritma mean-greedy memiliki beberapa langkah yaitu :

1. Menghitung rata-rata kualitas setiap user pada seluruh RB yang ada di sistem.

2. Mengurutkan user sesuai dengan kualitas rata-rata yang telah dihitung pada langkah 1 , mulai dari yang terkecil.

3. User dengan rata-rata terkecil dapat memilih $\mathrm{RB}$ yang memiliki kualitas terbaik sesuai dengan persamaan [8] :

$$
n^{*}=\arg \max _{v} C_{n, v}(s),
$$

dimana $n^{*}$ adalah RB $\mathrm{v}$ yang akan diberikan kepada user n. RB ke-v yang diberikan kepada user ke-n adalah RB dengan kualitas terbaik yang belum diberikan kepada user manapun. Setelah 1 RB diberikan kepada user yang spesifik, RB tersebut tidak dapat dipilih ataupun dipakai lagi oleh user lain. Hal ini sesuai dengan persamaan 3.

4. Proses nomor 4 akan dieksekusi berulang sampai semua RB teralokasikan.

Hasil dari algoritma ini adalah matriks CSI yang telah teralokasi tiap-tiap RB nya. Pada awalnya algoritma mean-greedy akan dilakukan dengan membagikan daya secara merata. Nantinya, setelah proses alokasi, akan ditambahkan skema kontrol daya waterfilling untuk mengatur daya yang dipakai tiap-tiap RB. Diagram alir dari algoritma mean greedy dapat dilihat pada gambar 1 .

\subsection{Kontrol Daya Waterfilling}

Pada penelitian ini akan digunakan 2 skema kontrol daya waterfilling yang berbeda. Skema pertama adalah Normal Waterfilling (NWF). Skema ini akan memeberikan daya lebih besar kepada user yang memiliki RB dengan kualitas buruk. Hal ini dilakukan untuk menjaga keadilan sistem. Kontrol daya ini akan mengikuti persamaan [11]:

$$
P_{n, v}(s)=\frac{H_{n, v}(s)}{\sum_{n=1}^{N} \sum_{v=1}^{V} H_{n, v}(s)} \times P_{t},
$$

dimana $P_{n, v}(s)$ adalah daya yang dialokasikan pada pasangan user ke-n dan RB ke-v, dan $P_{t}$ adalah daya total pada sistem. dengan persamaan ini, user dengan kondisi RB yang buruk akan mendapatkan power tambahan untuk menjaga kualitas layanannya.

Skema kedua adalah Inverse Waterfilling (IWF). Berkebalikan dengan NWF, IWF memberikan daya tambahan kepada user dengan keadaan kanal transmisi yang baik. Hal ini dimaksudkan untuk meningkatkan efisiensi energi dan efisiensi spektral. Skema IWF yang diterapkan sesuai dengan persamaan [11]:

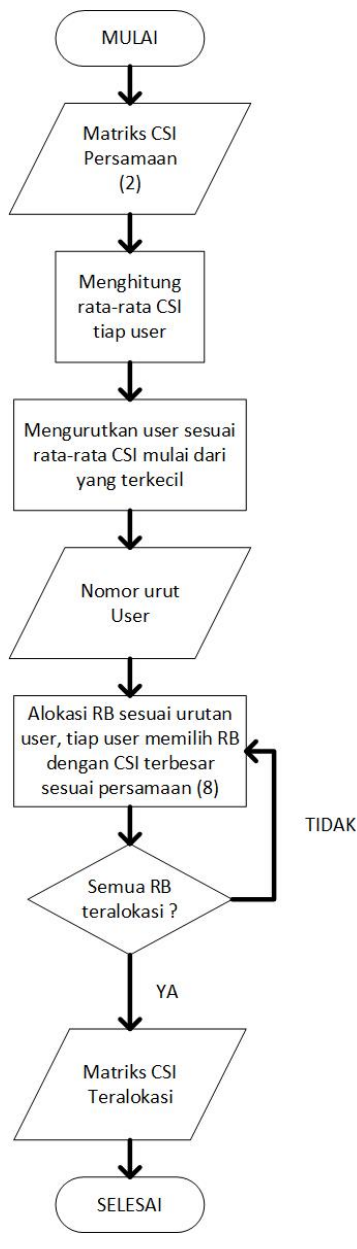

\section{Gambar 1. Diagram alir algoritma Mean Greedy}

$$
P_{n, v}(s)=\frac{\sum_{n=1}^{N} \sum_{v=1}^{V} \frac{1}{H_{n, v}(s)}}{H_{n, v}(s)} \times P_{t} .
$$

Diagram alir untuk proses waterfilling dapat dilihat pada gambar 2.

\subsection{Skema Manajemen Sumber Daya}

Secara keseluruhan, penelitian ini mencoba mengevaluasi pengaruh penggunaan skema kontrol daya berbasis waterfilling. Penelitian ini akan membandingkan performansi algoritma MG konvensional, kombinasi algoritma MG-NWF, dan MG-IWF. Langkah-langkah skema manajemen sumber daya pada penelitian ini adalah sebagai berikut :

1. Semua user mengukur kualitas masing-masing RB dengan asumsi power dialokasikan secara merata ke tiap-tiap RB.

2. Algoritma MG dieksekusi untuk mengalokasikan RB kepada 1 spesifik user.

3. Kontrol daya dieksekusi pada hasil keluaran algoritma MG untuk mengatur daya pada masing-masing pasangan RB-user. 


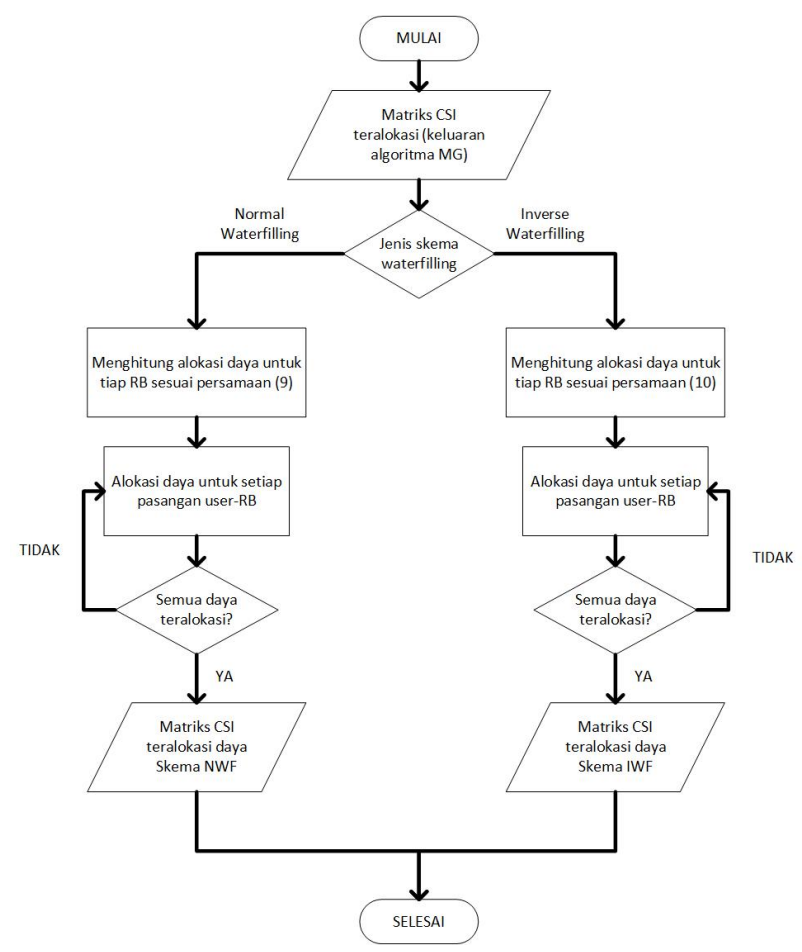

Gambar 2. Diagram alir skema waterfilling

4. Penghitungan performansi dari tiap-tiap algoritma untuk analisa hasil.

\section{Simulasi dan Analisis}

Simulasi dilakukan pada tiap-tiap algoritma dengan mangubah jumlah user pada sistem untuk melihat kecenderungan performansi algoritma saat keadaan jumlah user yang tinggi. Pada simulasi ini diasumsikan semua subcarrier saling orthogonal sehingga interferensi intracell tidak terjadi. Analisis performansi akan didasarkan pada 2 skenario. Pada skenario pertama, semua daya akan dialokasikan kepada semua user yang mendapatkan RB melalui skema waterfilling dengan mengikuti ketentuan pada persamaan 6, tanpa ada ketentuan daya minimal pada setiap RB.

Skenario kedua menggunakan ketentuan daya minimal pada tiap-RB. Awalnya, setiap RB akan menerima daya minimal $\mu$ yang sama untuk melakukan proses transmisi. Sisa daya yang belum teralokasikan kemudian akan dialokasikan kembali melalui skema waterfilling. sehingga persamaan formulasinya akan menjadi

$$
\beta_{n, v} \in[0, x] \mid \mu \leq x \leq P_{t} ; \forall_{v} \in V ; \forall_{n} \in V .
$$

Parameter performansi yang akan dianalisa pada penelitian ini adalah keadilan sistem (fairness), efisiensi spektral, dan efisiensi energi. Hasil dari simulasi akan dianalisa untuk melihat tingkat performansi dari tiap
Tabel 1. Parameter Simulasi

\begin{tabular}{|c|c|}
\hline Parameter Simulasi & Nilai \\
\hline Frekuensi carrier & $1800 \mathrm{MHz}$ \\
\hline Bandwidth carrier & $5 \mathrm{MHz}$ \\
\hline RB per carrier & 25 \\
\hline Bandwidth RB & $180 \mathrm{kHz}$ \\
\hline Jumlah pengulangan & 500 \\
\hline Jari-jari cell & $1 \mathrm{~km}$ \\
\hline Model propagasi & COST-231, tipe Urban \\
\hline Gain eNB & $18 \mathrm{dBi}$ \\
\hline Gain user & $0 \mathrm{dBi}$ \\
\hline Shadowing & lognormal, $\mu=0, \sigma=3$ \\
\hline Total daya pancar & 40 Watt $(46 \mathrm{dBm})$ \\
\hline Jumlah user & $50-100$, kenaikan 5 user \\
\hline
\end{tabular}

algoritma pada tiap skenario. Untuk parameter-parameter simulasi lain dapat dilihat pada tabel 1 [12].

\subsection{Hasil Skenario 1}

Simulasi pertama menggunakan skenario semua daya dialokasikan melalui proses waterfilling. Setelah proses alokasi RB, semua power akan dibagikan sesuai dengan skema kontrol daya, tanpa ada batas minimum daya yang akan dialokasi. Hasil dari skenario ini dapat dilihat pada Gambar 3-5.

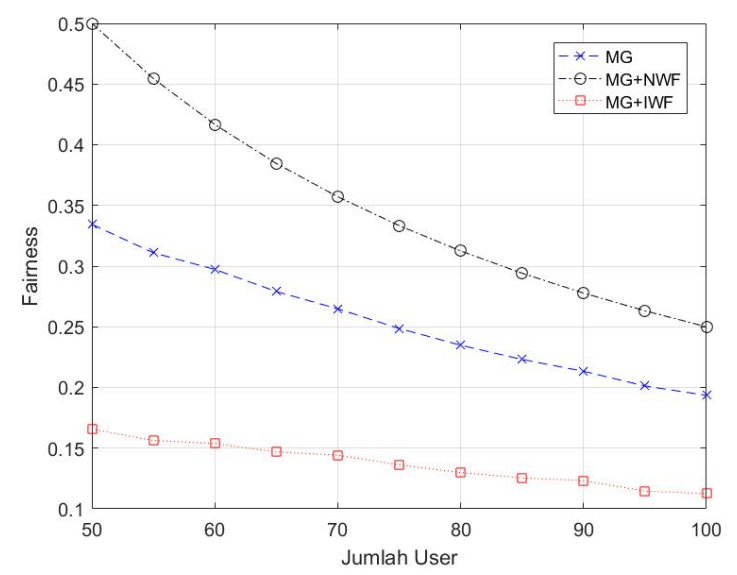

Gambar 3. Grafik fairness sistem tanpa daya
minimum

Dari hasil simulasi dapat disimpulkan bahwa kedua proses waterfilling menghasilkan grafik yang berbeda kecenderungan. Skema NWF memiliki fairness yang lebih bai, tetapi diikuti dengan menurunnya nilai efisiensi spektral dan efisiensi energi. Hal ini dikarenakan NWF mencoba mengakomodasi user dengan keadaan kanal rendah agar tetap mendapatkan kualitas layanan yang baik. Skema IWF meningkatkan fairness sebanyak 10\%, 


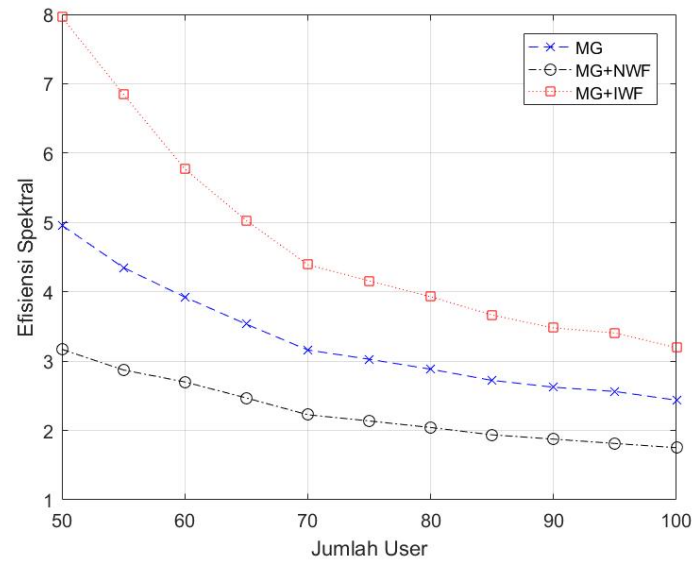

Gambar 4. Grafik efisiensi spektral tanpa daya minimum

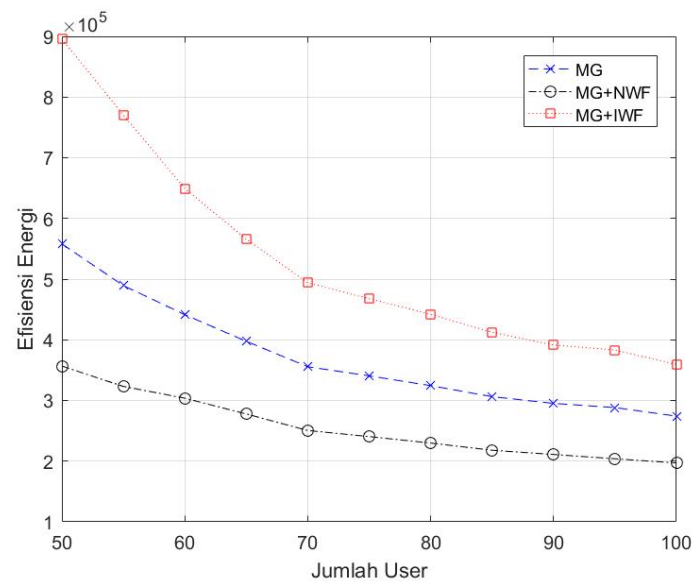

\section{Gambar 5. Grafik efisiensi energi tanpa daya minimum}

dengan menurunnya efisiensi spektral $1,02 \mathrm{bps} / \mathrm{Hz}$, dan efisiensi energi sebanyak 68,75 kbps/Watt.

Sedangkan skema IWF memiliki nilai efisiensi yang baik di kedua sisi (spektral dan energi), dengan diikuti dengan menurunnya nilai keadilan sistem (fairness). Hal ini diakibatkan karena skema IWF tidak membuang daya pada user dengan keadaan kanal rendah. Untuk memaksimalkan efisiensi, IWF mengalokasikan power hanya pada user dengan keadaan kanal baik. Skema IWF meningkatkan efisiensi spektral $1,42 \mathrm{bps} / \mathrm{Hz}$ dan efisiensi energi sebesar 205,67 kbps/Watt. Sedangkan di sisi fairness turun hingga $11 \%$.

\subsection{Hasil Skenario 2}

Pada skenario 2, tiap RB mendapatkan daya minimum sebesar 0,8 Watt, sehingga tidak semua daya sistem dialokasikan melalui skema waterfilling. Hasil

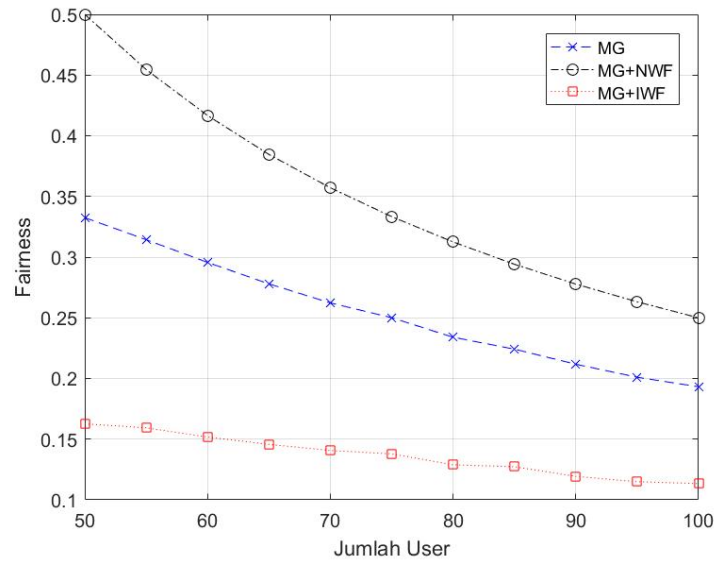

Gambar 6. Grafik fairness dengan daya minimum 0,8 Watt

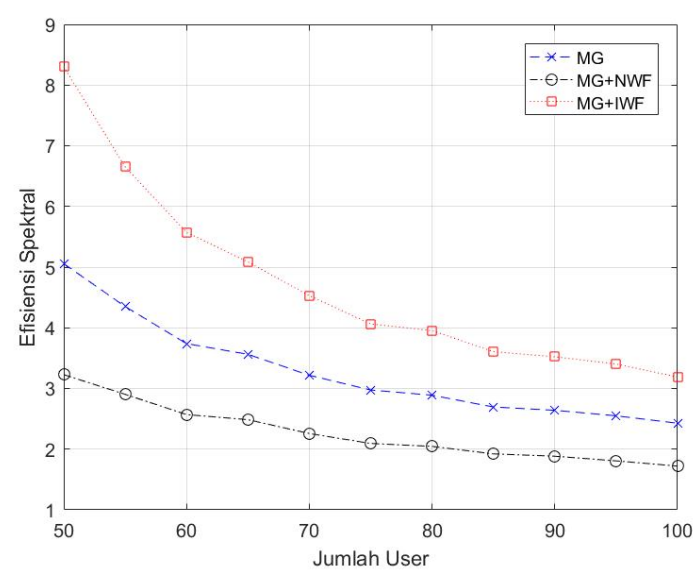

Gambar 7. Grafik efisiensi spektral dengan daya minimum 0,8 Watt

simulasi skenario 2 dapat dilihat pada Gambar 6-8.

Hasil pada skenario ini memiliki kecenderungan yang sama dengan skenario $1 . \quad$ Nilai rata-rata parameternya pun hampir mendekati satu sama lain. Hal ini menandakan diterapkannya daya minimum tiap RB tidak banyak berpengaruh pada sistem secara keseluruhan. Hasil simulasi keseluruhan secara kuantitatif dapat dilihat pada Tabel 2.

\section{Kesimpulan}

Pada penelitian ini telah disimulasikan dua skema kontrol daya waterfilling yang berbeda pada skema alokasi sumber daya mean greedy di sistem LTE. Dari hasil simulasi terlihat bahwa kedua skema waterfilling ini memiliki kecenderungan yang berbeda.

Skema pertama yaitu Normal Waterfilling (NWF) yang mengalokasikan lebih banyak daya pada user 


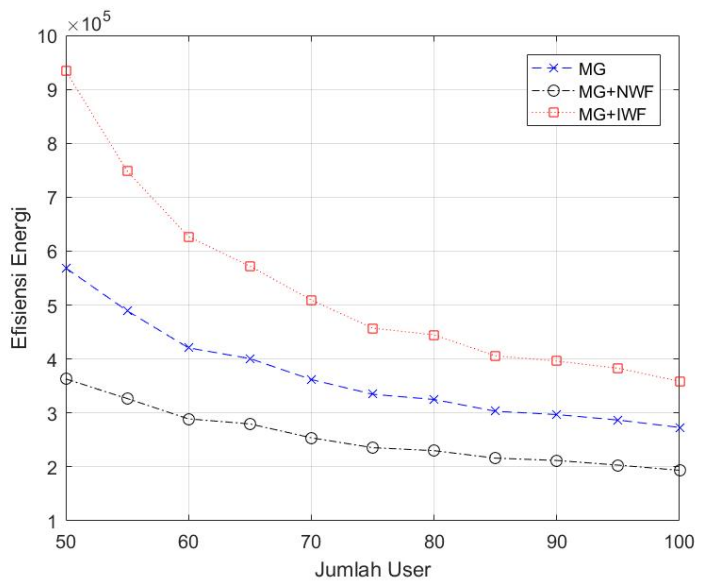

Gambar 8. Grafik efisiensi energi dengan daya
minimum 0,8 Watt

dengan kanal buruk. Hal ini dimaksudkan untuk menjaga kualitas layanan user tersebut. Pada skema ini terjadi kenaikan nilai fairness rata-rata sistem sebesar $10 \%$. Pada parameter efisiensi, nilai efisiensi spektral turun sebesar $1,02 \mathrm{bps} / \mathrm{Hz}$, sedangkan efisiensi energi turun sebesar 68,75 kbps/Watt.

Skema kedua Invers Waterfilling (IWF) mengalokasikan lebih banyak daya pada user dengan keadaan kanal baik. Hal ini dimaksudkan untuk memaksimalkan efisiensi energi dan spektral agar tidak terlalu banyak daya yang terdisipasi pada user dengan kanal buruk. Dari hasil simulasi didapatkan skema ini meningkatkan efisiensi spektral sebanyak $1,42 \mathrm{bps} / \mathrm{Hz}$, dan meningkatkan efisiensi energi sebanyak 205,67 kbps/Watt. Tetapi fairness sistem menurun sebanyak 11\%. Hal ini dikarenakan terjadi ketidakadilan kualitas layanan antar user pada sistem.

Pada penelitian ini juga dicoba pemberian daya minimum untuk masing-masing RB. tetapi skenario ini ternyata tidak berpengaruh pada performansi sistem secara keseluruhan. Hasil dari simulasi memperlihatkan adanya kesamaan kecenderungan antara kedua skenario.

\section{Daftar Pustaka}

[1] Y. Ma, "Proportional fair scheduling for downlink ofdma," in Communications, 2007. ICC'07. IEEE International Conference on. IEEE, 2007, pp. 4843-4848.

[2] N. M. Adriansyah, M. Asvial, and B. Budiardjo, "Modified greedy physical link scheduling algorithm for improving wireless mesh network performance," TELKOMNIKA (Telecommunication Computing Electronics and Control), vol. 13, no. 1, pp. 202-210, 2015.
Tabel 2. Hasil simulasi tiap algoritma pada masing-masing skenario

\begin{tabular}{|c|c|c|c|}
\hline \multirow{2}{*}{ Parameter } & \multirow{2}{*}{ Algoritma } & \multicolumn{2}{|c|}{ Nilai rata-rata } \\
\cline { 3 - 4 } & & Skenario 1 & Skenario 2 \\
\hline Efisiensi & MG & 3,29 & 3,28 \\
\cline { 2 - 4 } $\begin{array}{c}\text { Spektral } \\
\text { (bps/Hz) }\end{array}$ & MG-NWF & 2,27 & 2,27 \\
\cline { 2 - 4 } $\begin{array}{c}\text { Efisiensi } \\
\text { Energi } \\
\text { (kbps/Watt) }\end{array}$ & MG & 324,40 & 3,72 \\
\cline { 2 - 4 } & MG-NWF & 255,65 & 254,21 \\
\hline \multirow{3}{*}{ Fairness } & MG-IWF & 530,07 & 530,58 \\
\cline { 2 - 4 } & MG-NWF & 0,25 & 0,25 \\
\cline { 2 - 4 } & MG-IWF & 0,35 & 0,35 \\
\hline
\end{tabular}

[3] O. Nwamadi, X. Zhu, and A. K. Nandi, "Multicriteria ranking based greedy algorithm for physical resource block allocation in multi-carrier wireless communication systems," Signal Processing, vol. 92, no. 11, pp. 2706-2717, 2012.

[4] _ - "Dynamic physical resource block allocation algorithms for uplink long term evolution," IET communications, vol. 5, no. 7, pp. 1020-1027, 2011.

[5] A. Fahmi, M. Asvial, and D. Gunawan, "Combinedorder algorithm using promethee method approach and analytic hierarchy decision for chunk allocation in lte uplink systems," International Journal of Communication Networks and Information Security (IJCNIS), vol. 5, no. 1, 2013.

[6] _ - "Improved performance of mean greedy algorithm for chunk allocation in sc-fdma uplink systems using joint-user and chunkbased allocation," Journal of ICT Research and Applications, vol. 7, no. 1, pp. 59-81, 2013.

[7] A. Fahmi, R. P. Astuti, L. Meylani, and V. S. W. Prabowo, "Utilizing mean greedy algorithm using user grouping for chunk allocation in ofdma systems with carrier aggregation," in Telecommunication Systems Services and Applications (TSSA), 2015 9th International Conference on. IEEE, 2015, pp. 1-4.

[8] V. S. W. Prabowo, A. Fahmi, and D. Perdana, "Modified mean greedy allocation algorithm in ofdma system with carrier aggregation," Advanced Science Letters, vol. 23, no. 5, pp. 3939-3943, 2017.

[9] K. Yang, S. Martin, T. A. Yahiya, and J. Wu, "Energy-efficient resource allocation for downlink in lte heterogeneous networks," in Vehicular Technology Conference (VTC Fall), 2014 IEEE 80th. IEEE, 2014, pp. 1-5. 
[10] R. C. Ginting, N. Andini, A. Fahmi, and V. S. W. Prabowo, "Waterfilling power control on proportional fair algorithm to maintain fairness and saves power for mimo-ofdma $2 \times 2$," in 2018 4th International Conference on Science and Technology (ICST), vol. 1. IEEE, 2018, pp. 1-5.

[11] A. F. Molisch, Wireless communications. John
Wiley \& Sons, 2012, vol. 34.

[12] S. Shi, C. Feng, and C. Guo, "A resource scheduling algorithm based on user grouping for lteadvanced system with carrier aggregation," in 2009 International Symposium on Computer Network and Multimedia Technology. IEEE, 2009, pp. 1-4. 